\title{
NEW MOLECULAR MECHANISM OF CEFTAZIDIME-INDUCED HUMAN RED BLOOD CELL HEMOLYSIS THROUGH THE PHOTOHEMOLYSIS REACTION
}

\author{
MASHURI MASHURI ${ }^{1 *}$, ACHMAD ZAINI ${ }^{2}$, DIANA RAHMANISA ${ }^{2}$, MUHAMMAD RIFQI ALFIANNOOR², \\ MUHAMMAD ROSYHAN SANJAYA ${ }^{2}$, EKO SUHARTONO ${ }^{3}$
}

${ }^{1}$ Department of Radiology, Faculty of Medicine, University of Lambung Mangkurat, Banjarmasin, South Kalimantan, Indonesia. ${ }^{2}$ Faculty of Medicine, University of Lambung Mangkurat, Banjarmasin, South Kalimantan, Indonesia. ${ }^{3}$ Department of Medical Chemistry/Biochemistry, Faculty of Medicine, University of Lambung Mangkurat, Banjarmasin, South Kalimantan, Indonesia. Email: ekoantioxidant@gmail.com

Received: 28 August 2018, Revised and Accepted: 29 August 2018

ABSTRACT

Objective: The present study was undertaken to investigate the photohemolysis reaction through photosensitization reaction by ceftazidime as a photosensitizer in human red blood cell (RBC).

Methods: In this present study, human erythrocytes have used a sample. The sample then divided into six groups consisting of Group 1 (T1) served a negative control which consists of erythrocytes and buffers phosphate with pH 6.8; Group 2 (T2) served as a positive control which consists erythrocytes and buffers phosphate with pH 6.8 and exposed to UV-light; and Group 3, 4, 5, and 6 (T3, T4, T5, and T6) served as an experimental group which consists of erythrocytes, buffer phosphate with $\mathrm{pH} 6.8$, ceftazidime with concentration 10\%, 20\%, 30\%, and 40\%, respectively, and also exposed to UV-light. UV-light exposure was done in $2 \mathrm{~h}$. After the treatment period, the level of hydrogen peroxide ( $\left.\mathrm{H}_{2} \mathrm{O}_{2}\right)$, conjugated diene (CD), advanced oxidation protein products (AOPPs), and percentage of RBC hemolysis (RBCH) were measured.

Results: The results of this present studies showed that ceftazidime significantly increases the levels of $\mathrm{H}_{2} \mathrm{O}_{2}$, $\mathrm{CD}, \mathrm{AOPPs}$, and percentage of RBCH during the UV radiation.

Conclusion: The present study demonstrated that ceftazidime acts as a photosensitizer and induced the photohemolysis reaction in human RBC. Furthermore, the hemolysis of RBC seems through the protein damage than lipid damage.

Keywords: Ceftazidime, Photohemolysis, Photosensitization, Photosensitizer.

(C) 2018 The Authors. Published by Innovare Academic Sciences Pvt Ltd. This is an open access article under the CC BY license (http://creativecommons. org/licenses/by/4. 0/) DOI: http://dx.doi.org/10.22159/ajpcr.2018.v11i3.30029.

\section{INTRODUCTION}

Sunlight is known contain some continuous spectrum electromagnetic radiation. These radiation is differentiated into three parts such as ultraviolet, visible, and infrared [1]. Among these three main parts, UV light is the most important part especially for the human body [2]. UV light wavelength zone occurs between 100 and $400 \mathrm{~nm}$. In general, these wavelength regions are classified into three parts, among others UVC radiation (200-290 $\mathrm{nm}$ ), UVB radiation (290-320 $\mathrm{nm})$, and UVA radiation $(320-400 \mathrm{~nm})$. Furthermore, the UV radiation that reaches the earth's surface contains about $5 \%$ of UVB and $95 \%$ of UVA radiation. However, because of the damage of the Protection ozone the UVB radiation was increased $[1,2]$.

Both UVA and UVB could induce the phototoxicity reactions with the presence of chemical substances called photosensitizer $[3,4]$. Photosensitizer is a substance which could absorb light and change from a low energy ground state to an excited state. Furthermore, these excited states of photosensitizer can interact with oxygen to form singlet oxygen and another reactive oxygen species (ROS) [5]. However, this ROS could promote a further reaction to oxidized lipid and/or protein, and DNA resulted in cellular damage [5].

It is well known that many drugs could act as a photosensitizer. One of a common source is antimicrobials. The most widely studied antibiotic on this pathomechanism is quinolones. However, the previous report suggested another antimicrobial which is potentially as a photosensitizer, such as ceftazidime [6]. Ceftazidime is a broadspectrum antibiotics. It is the third generation of cephalosporin and semisynthetic. It has broad- spectrum activity against Gram-positive and Gram-negative. However, unlike most third-generation agents, it is active against Pseudomonas aeruginosa. This antibiotic is administered parenterally every 8-12 h (2-3 times a day), with daily dosages of 500-6,000 mg, determined by the indication, infection severity, and/or renal function of the patient [7].

It is well known, the administration of drugs such as antibiotics can induce the blood cell hemolysis. Although drug-induced hemolysis is less common than other types of adverse reactions, they are associated with significant morbidity and mortality [7]. Arndt [8] reported that there are some antibiotics could induce the blood cell hemolysis including ceftazidime. Previous reports indicated ceftazidime induced immune hemolytic anemia on red blood cells (RBC) only and RBCs with the addition of plasma in two of the four methods performed and in three of four methods performed, respectively [8]. However, there are 4 proposed mechanisms in the drug-induced hemolysis such as (1) hapten or drug adsorption mechanism; (2) innocent bystander mechanism; (3) RBC autoantibodies mechanism; and (4) nonimmunologic protein adsorption mechanism [9].

However, in this present study, we propose another mechanism which is photohemolysis mechanism. In this mechanism, ceftazidime acts as a photosensitizer and with the UV radiation-induced the photohemolysis reaction. To investigate this mechanism reaction, four parameters will be measured such as hydrogen peroxide $\left(\mathrm{H}_{2} \mathrm{O}_{2}\right)$ as a one of photosensitization reaction product, conjugated diene (CD), and advanced oxidation protein products (AOPPs) as an impact of photosensitization reaction product formation, and the percentage 
of RBCs hemolysis (RBCH) to assess the damage of RBCs during this reaction. To explain the mechanism of RBCH due to ceftazidime, we also correlated $\mathrm{CD}$ and AOPPs with the percentage of $\mathrm{RBCH}$.

\section{METHODS}

\section{Sample preparation and experimental section}

The packed red cells with $250 \mathrm{ml}$ volume were obtained from the Indonesian Red Cross in Martapura, Banjar District, South Kalimantan, Indonesia. Then, the samples were divided into 6 groups with each group performed four replications. Treatment 1 (T1) group served as a negative control which consists of $1 \mathrm{ml}$ of erythrocytes and buffers phosphate with $\mathrm{pH}$ 6.8. Treatment (T2) group served as a positive control which consists of $1 \mathrm{ml}$ of erythrocytes and buffer phosphate with pH 6.8 and exposed to UV-light for 2 h. Treatment 3, 4, 5, and 6 (T3, T4, T5, and T6) served as an experimental group which consists $1 \mathrm{ml}$ of erythrocytes, buffer phosphate with $\mathrm{pH}$ 6.8, ceftazidime with concentration $10 \%, 20 \%, 30 \%$, and $40 \%$, respectively, and exposed to UV-light for $2 \mathrm{~h}$. After treatment, each solution will be measured the $\mathrm{H}_{2} \mathrm{O}_{2}, \mathrm{CD}$, AOPPs levels, and percentage of RBCH. (Experiments performed complied with the guidelines of the Institute of Laboratory Animal Resources, Commission on Life Sciences, National Research Council and were approved by the Ethical Committee of the Faculty of Medicine, University of Lambung Mangkurat, Banjarbaru, South Kalimantan, Indonesia [ethical approval number; 403/KEPK-FK UNLAM/EC/VI/2017]).

\section{$\mathrm{H}_{2} \mathrm{O}_{2}$ concentration analysis}

The $\mathrm{H}_{2} \mathrm{O}_{2}$ level was calculated by the $\mathrm{FOX}$ method with slight modification [10]. Solutions measured spectrophotometrically at $\lambda=505 \mathrm{~nm}$. Standard and test solutions consisted of $1 \mathrm{M} \mathrm{H}_{2} \mathrm{O}_{2} 200 \mu \mathrm{L}$ and $200 \mu \mathrm{L}$ serum, respectively, with the addition of $160 \mu \mathrm{L} \mathrm{PBS} \mathrm{pH} \mathrm{7.4,}$ $160 \mu \mathrm{L} \mathrm{FeCl}_{3} 251.5 \mathrm{mg} \mathrm{FeCl}$ dissolved in $250 \mathrm{ml}$ distilled water) and $160 \mu \mathrm{L}$ o-phenanthroline $(120 \mathrm{mg}$ o-phenanthroline dissolved in $100 \mathrm{ml}$ distilled water) for both solutions. The composition of the blank solution was identical to that of the test solution, except for the absence of $\mathrm{FeCl}_{3}$ in the blank. Subsequent to preparation, all solutions were incubated for $30 \mathrm{~min}$ at room temperature, then centrifuged at 12,000 rpm for $10 \mathrm{~min}$, and the absorbance of the standard (As), test $(\mathrm{Au})$, and blank $(\mathrm{Ab})$ solutions measured at $\lambda=505 \mathrm{~nm}$, using the supernatant of each solution [11].

\section{CD concentration analysis}

CD concentration was assayed as previously described by Recknagel [12] with minor modifications. Briefly, the sample extracted with chloroform: methanol (2:1) at a ratio of 1:2.5 homogenate to the organic solvent mixture. The resulting mixture was centrifuged at $2000 \mathrm{rpm}$ for $8 \mathrm{~min}$. The organic phase containing the CD was taken, dried under nitrogen, solubilized in hexane, and rinsed with $0.003 \mathrm{~N}$ $\mathrm{HCl}$. Samples were analyzed spectrophotometrically at $233 \mathrm{~nm}$, the maximal absorbance for $\mathrm{CD}$, and expressed per nanomole of phosphate. Total phosphates were quantified by incubating a portion of the dried organic phase for $3 \mathrm{~h}$ with $70 \%$ perchloric acid at $130^{\circ} \mathrm{C}$, followed by the addition of ammonium molybdate and Fiske-Subbarow reagent. Samples or standards were then reheated to $110^{\circ} \mathrm{C}$ for $10 \mathrm{~min}$, cooled, and analyzed spectrophotometrically at $820 \mathrm{~nm}$. Data are expressed as optical density at $233 \mathrm{~nm} / \mathrm{nmol}$ phosphate.

\section{AOPPs concentration analysis}

AOPPs concentration analyses were calculated by spectrophotometric methods. $200 \mu \mathrm{l}$ of supernatant from the kidney homogenate was diluted with phosphate buffer solution and then placed on 96-test wells. Add $20 \mathrm{ml}$ of acetic acid in each test well. For the standard, add $10 \mathrm{ml}$ of $1.16 \mathrm{~mol}$ potassium iodide, $200 \mathrm{ml}$ of chloramine-T solution (0-100 $\mathrm{mmol} / \mathrm{l})$, and $20 \mathrm{ml}$ of acetic acid. Placed the standard mixture into standard wells. Then, read the absorbance of the mixture at $340 \mathrm{~nm}$. The absorbance was read against a blank solution. A blank solution is a mixture between $200 \mathrm{ml}$ of phosphate buffer solution, $10 \mathrm{ml}$ of potassium iodide, and $20 \mathrm{ml}$ of acetic acid. AOPPs concentrations were expressed as mmol/l of chloramine-T equivalents [13].

\section{RBCH percentage analysis}

A suspension of erythrocyte $(500 \mu$ l) within a micro-tube was incubated for the required times with an equal volume of the test sample mixture, prepared in the buffer at $37^{\circ} \mathrm{C}$. After incubation, the mixture was spun in a microcentrifuge at $2600 \mathrm{rpm}$ for $10 \mathrm{~min}$, and $200 \mu \mathrm{l}$ of the resulting supernatants was added to $4.5 \mathrm{ml}$ of Drabkin's reagent. To assay for hemoglobin released, the absorbance of samples was assessed in $546 \mathrm{~nm}$ wavelength using spectrophotometer. Positive controls consisted of $500 \mu \mathrm{l}$ of uncentrifuged mixtures of erythrocyte suspensions and $500 \mu \mathrm{l}$ of buffer, which was added to $3 \mathrm{ml}$ Drabkin's reagent to obtain a value for $100 \%$ hemolysis. A negative control, included to measure the level of spontaneous hemolysis, comprised $500 \mu \mathrm{l}$ buffer mixed with $500 \mu \mathrm{l}$ erythrocytes, and after centrifugation for $10 \mathrm{~min}$, a $200 \mu \mathrm{l}$ sample of supernatant was added to $3 \mathrm{ml}$ of Drabkin's reagent. Hemolysis percentage for each sample was calculated by dividing sample's absorbance on positive control absorbance (complete hemolysis) multiplied by $100 \%$ [14].

\section{Statistical analysis}

The results were expressed as mean \pm SE for four replicates. Significance of mean differences of all parameters between treatment and control groups was statistically compared using one-way analysis of variance and followed by a post hoc Tukey's Honestly Significant Difference test for multiple range test.

To determine the mechanism of $\mathrm{RBCH}$ due to ceftazidime, the percentage of $\mathrm{RBCH}$ was correlated to $\mathrm{CD}$ and AOPPs concentrations.

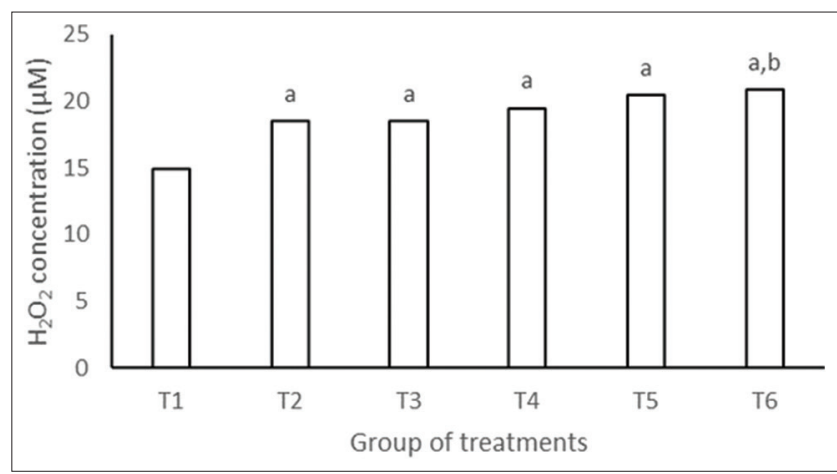

Fig. 1: It shows the effect of different concentration of ceftazidime during UV-light radiation on $\mathrm{H}_{2} \mathrm{O}_{2}$ concentration. Values are a mean \pm standard error of the mean of four replicates in each group of treatment. Statistical significance ${ }^{\mathrm{a}} \mathrm{p}<0,05$ in comparison with negative control group (T1), ${ }^{\mathrm{b}} \mathrm{p}<0.05$ in comparison with negative control group (T2)

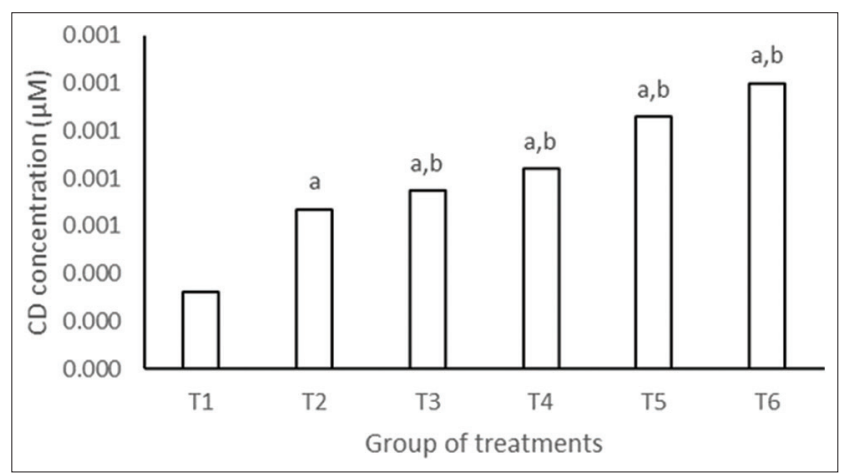

Fig. 2: It shows the effect of different concentration of ceftazidime during UV-light radiation on conjugated diene concentration.

Values are mean \pm standard error of the mean of four replicates in each group of treatment. Statistical significance ${ }^{\mathrm{a}} \mathrm{p}<0.05$ in comparison with negative control group (T1), ${ }^{b} p<0.05$ in comparison with negative control group (T2) 
The Pearson correlation test was used to analyze the relationship between those variables and the correlation coefficient $(r)$ was derived to measure the strength of association between $\mathrm{RBCH}$ and both parameters that produced due to ceftazidime and during irradiation with UV. Significance was set at $\mathrm{p}<0.05$. The software used for the data analysis was the Statistical Package for the Social Sciences version 16.0 and Microsoft Excel 2016 for Windows 10.

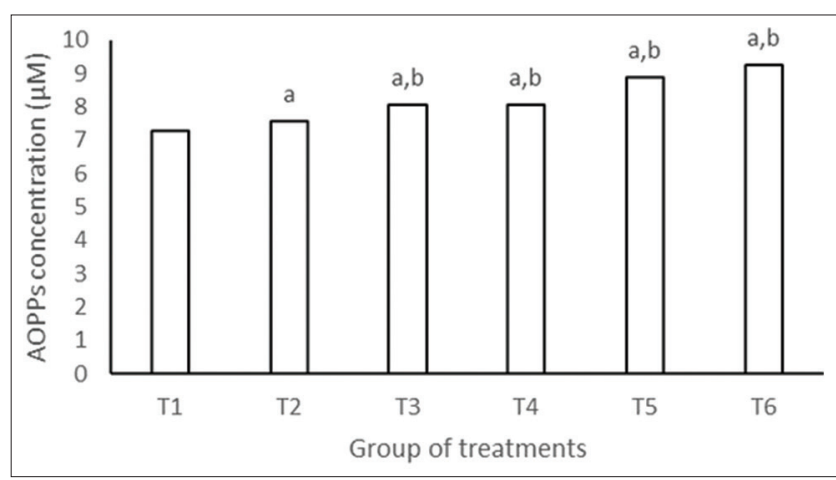

Fig. 3: It shows the effect of different concentration of ceftazidime during UV-light radiation on advanced oxidation protein products concentration. Values are a mean \pm standard error of the mean of four replicates in each group of treatment. Statistical significance ${ }^{a} p<0.05$ in comparison with negative control group (T1), ${ }^{b} p<0.05$ in comparison with negative control group (T2)

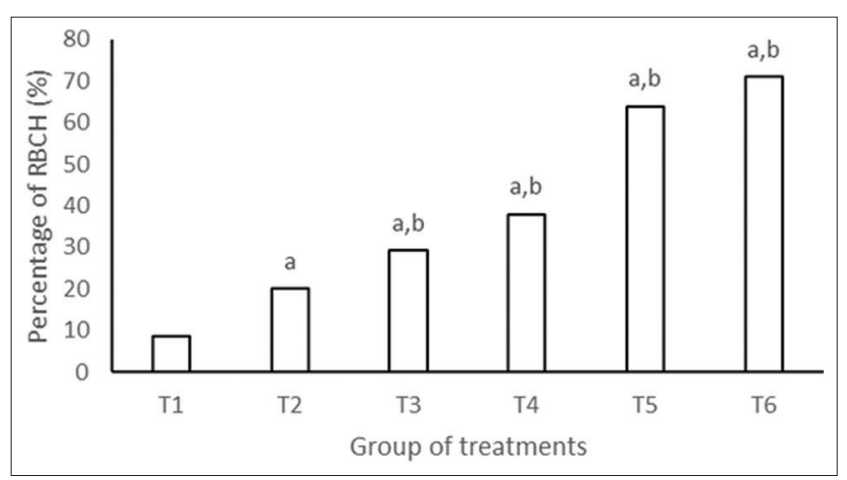

Fig. 4: It shows the effect of different concentration of ceftazidime during UV-light radiation on the percentage of red blood cells hemolysis concentration. Values are a mean \pm standard error of the mean of four replicates in each group of treatment. Statistical significance ${ }^{\mathrm{a}} \mathbf{p}<0.05$ in comparison with negative control group (T1), ${ }^{\mathrm{b}} \mathrm{p}<0.05$ in comparison with negative control group (T2)

\section{RESULTS AND DISCUSSION}

In this present study, we try to investigate that antibiotics like ceftazidime could induce blood cell hemolysis through the photohemolysis reaction. It was based on phototoxicity reaction which is started when blood cells are exposed to UV radiation and are photosensitized by ceftazidime. Ceftazidime in this reaction is called a photosensitizer. Ceftazidime could absorb photon from the UV-light which is electromagnetic spectrum and converted into chemical energy used in chemical reactions. These chemical reactions can lead to the formation of some ROS, such as $\mathrm{H}_{2} \mathrm{O}_{2}[6,15]$. It can be seen from the result of this present study (Fig. 1).

According to Fig. 1, it can be seen that ceftazidime could increase the $\mathrm{H}_{2} \mathrm{O}_{2}$ formation. However, statistically, only the largest dose of ceftazidime could significantly increase the $\mathrm{H}_{2} \mathrm{O}_{2}$ level. To the best of our knowledge, there have been no investigations of the association between ceftazidime, UV-light radiation, and the formation of $\mathrm{H}_{2} \mathrm{O}_{2}$. Nonetheless, previous literature has suggested that antibiotics such as ceftazidime may trigger phototoxicity reactions and produce ROS [6].

As a result of increased levels of ROS during this photoxicity reaction, lipid and/or protein oxidation can occur. It was supported by the result of this present study. The result revealed that ceftazidime in all concentrations with UV-light exposure could significantly increase the level of CD and AOPPs (Figs. 2 and 3). This results also supported by another our previous reports that were indicated that ceftazidime could induce the formation of malondialdehyde and protein carbonyl during UV-light radiation [16].

Lipid and/or protein oxidation by ROS commonly used several biomarkers, such as CD and AOPPs. CD was reported as a marker for the early stage of lipid oxidation [17]. These compound formed at the initiation stage of lipid oxidation from the intramolecularly arrangement of lipid radical [18]. Furthermore, AOPPs was known as a product of the action of free radicals on proteins which is first described by Witko-Sarsat et al. AOPPs are defined as dityrosine containing crosslinked protein products and are considered to be reliable biomarkers to estimate the degree of protein oxidation [19]

Lipid and/or protein oxidation will promote a further reaction resulted in cell damage. From this point of view, cell damage that will occur in this study is damage to RBC. Fig. 4 shows that the percentage of RBCH is significantly increase in all concentration of ceftazidime. This result indicated that ceftazidime could induce hemolysis of RBC. To investigate which mechanism triggers $\mathrm{RBCH}$, the levels of $\mathrm{CD}$ and AOPPs are correlated with percentages of RBCH. The results show in Fig. 5a and b.

According to Fig. 5a and b, both parameters have a significant strong positive correlation with the percentage of RBCH. However, if we look closely to the $r$ value, AOPPs have a larger $r$ value (0.992) than CD

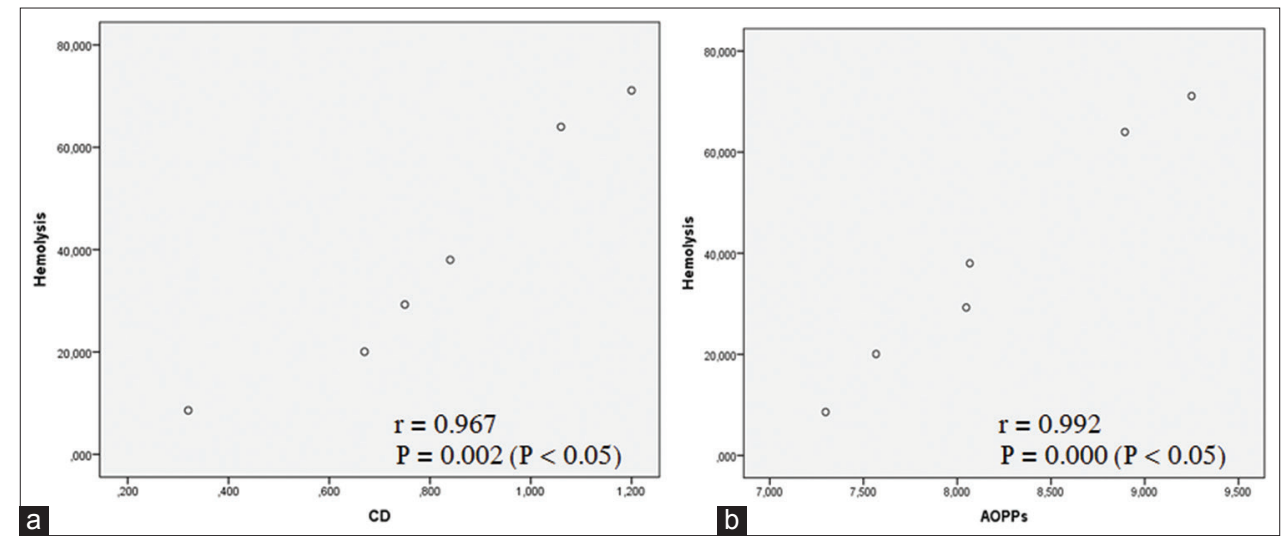

Fig. 5: It shows the correlation between percentage of red blood cells hemolysis and (a) conjugated diene and (b) advanced oxidation protein products concentrations by different concentration of ceftazidime during UV-light radiation 
(0.967). These results prove that $\mathrm{RBCH}$ is more due to protein damage than lipid damage. To the best of our knowledge, there have been no investigations of the association between those all parameters by ceftazidime during UV-light radiation.

\section{CONCLUSION}

It can be concluded from the presented results that ceftazidime induced photohemolysis reaction in RBC. Moreover, from the results, the photohemolysis reaction might be followed by a photosensitization reaction, in which ceftazidime acts as a photosensitizer and uses UVlight to induce RBCH. Furthermore, from the results, it seems that the $\mathrm{RBCH}$ is more due to protein damage than lipid damage. Further studies are undergoing to clarify their molecular mechanisms.

\section{REFERENCES}

1. Mishra P, Sharma A, Kumar S. In vitro effect of Uv-b radiation on goat erythrocytes in presence of photosensitizers. Int J Integr Biol 2012;13:52-7.

2. Karlsson I. Chemical and Dermatological Aspects of UV-Absorbing Compounds [dissertation]. Goteborg (Sweden): University of Gothenburg; 2011.

3. Onoue S, Seto Y, Oishi A, Yamada S. Novel methodology for predicting photogenotoxic risk of pharmaceutical substances based on reactive oxygen species (ROS) and DNA-binding assay. J Pharm Sci 2009;98:3647-58.

4. Quintero B, Miranda MA. Mechanisms of photosensitization induced by drugs: A general survey. Ars Pharm 2000;41:27-46.

5. Shivanna V, Nilegaonkar R. Photodynamics in dentistry. CODS J Dent 2015;7:13-8

6. Gill L, Lim HW. Drug-induced photosensitivity. In: Hall JC, Hall BL, editors. Cutaneous Drug Eruptions: Diagnosis, Histopathology and Therapy. London: Springer-Verlag London; 2015. p. 107-21.

7. Wijesooriya C, Budai M, Budai L, Szilasi ME, Petrikovics I.
Optimization of liposomal encapsulation for ceftazidime for developing a potential eye drop formulation. J Basic Clin Pharm 2013;4:73-5.

8. Arndt PA. Drug-induced immune hemolytic anemia: The last 30 years of changes. Immunohematology 2014;30:44-54.

9. Rao KV. Drug-Induced Hematologic Disorders. New York: McGrawHill; 2014. p. 359-74.

10. Yunanto A, Iskandar, Suhartono E. In-vitro effects of some antibiotic drugs on saliva thiocyanate and oxidation protein products levels on newborn at risk of sepsis. Int J Pharm Clin Res 2016;8:86-9.

11. Karantika EA, Edyson S, Suhartono E. Kinetic parameters analysis of liver and kidney catalase under the influence of cadmium $(\mathrm{Cd})$ and mercury (Hg) in vitro. J Trop Life Sci 2016;6:65-8.

12. Recknagel A, Steiner A, Brooker S, Stalke D, Edelmann FT. Organolanthanide (II) chemistry: Synthesis and structure of [Cp*2Sm(OC)2FeCp*]2. Chem Ber 1991;124:1373-5.

13. Suhartono E, Yunanto A, Hartoyo E, Kania N, Utama AA, Sari RK, et al. UV-Visible spectrophotometric as a prospective tool in neonatal sepsis. Indones Biomed J 2018 Article in Press.

14. Noudeh GD, Sharififar F, Khatib M, Behravan E, Afzadi MA. Study of aqueous extract of three medicinal plants on cell membranepermeabilizing and their surface properties. Afr $\mathrm{J}$ Biotechnol 2010;9:110-6.

15. Nayak P. Commonly used photosensitizing medications: Their adverse effects and precautions to be considered. Int J Pharm Sci Rev Res 2010;4:135-40.

16. Mashuri M, Ruhullah M, Putera BD, Mega VP, Putra FA, Suhartono E. The role of ceftazidime as a photosensitizer in human erythrocytes through oxidative stress mechanism. Indones Biomed J 2018. Article in Press.

17. Meksiarun P, Maeda Y, Hiroi T, Andriana BB, Sato H. Analysis of the effects of dietary fat on body and skin lipids of hamsters by Raman spectroscopy. Analyst 2015;140:4238-44.

18. Colak E. New markers of oxidative damage to macromolecules. JMB 2008;27:1-16

19. Ma Y, Zhang L, Rong S, Qu H, Zhang Y, Chang D, et al. Relation between gastric cancer and protein oxidation, DNA damage, and lipid peroxidation. Oxid Med Cell Longev 2013;2013:543760. 